\title{
A balancing act: a window into online student engagement experiences
}

\author{
Orna Farrell (1) and James Brunton(1)
}

\author{
* Correspondence: orna.farrell@dcu. \\ ie \\ National Institute for Digital \\ Learning, Dublin City University, Bea \\ Orpen Building, Glasnevin Campus, \\ Dublin 9, Ireland
}

\begin{abstract}
This article reports on a qualitative study which explored online student engagement experiences in a higher education institution. There are very few studies providing in-depth perspectives on the engagement experiences of online students. The project adopted a case study approach, following 24 online students over one academic year. The setting for the study was an undergraduate online Humanities programme at Dublin City University. The research question for the study was: What themes are central to online student engagement experiences? Data was collected from participant-generated learning portfolios and semi-structured interviews and analysed following a data-led thematic approach. The five central themes that make up the study's findings highlight key issues of students' sense of community, their support networks, balancing study with life, confidence, and their learning approaches. The findings of this study indicate that successful online student engagement was influenced by a number of psychosocial factors such as peer community, an engaging online teacher, and confidence and by structural factors such as lifeload and course design. One limitation of the study is that it is a relatively small, qualitative study, its findings provide insights into how online degrees can support online students to achieve successful and engaging learning experiences.
\end{abstract}

Keywords: Online student, Student engagement, Student success, Online learning, Qualitative, Student voice, Lifeload

\section{Introduction}

This study set out to explore the central themes relating to online student engagement experiences. A case study approach was adopted, following 24 online students over one academic year as they studied towards a BA in Humanities degree through DCU Connected, in Dublin City University (DCU). DCU Connected delivers flexible, undergraduate and postgraduate programmes through the mode of online learning and aims to afford educational opportunities to students who have not managed to access more traditional entry routes into higher education.

Online learning is the fastest growing areas of education worldwide because it provides access to educational opportunities in a flexible manner to students from diverse backgrounds and geographical regions who often can't access higher education by other means (Delaney \& Fox, 2013; Roll, Russell, \& Gašević, 2018). In Ireland, online

(c) The Author(s). 2020 Open Access This article is licensed under a Creative Commons Attribution 4.0 International License, which permits use, sharing, adaptation, distribution and reproduction in any medium or format, as long as you give appropriate credit to the original author(s) and the source, provide a link to the Creative Commons licence, and indicate if changes were made. The images or other third party material in this article are included in the article's Creative Commons licence, unless indicated otherwise in a credit line to the material. If material is not included in the article's Creative Commons licence and your intended use is not permitted by statutory regulation or exceeds the permitted use, you will need to obtain permission directly from the copyright holder. To view a copy of this licence, visit http://creativecommons.org/licenses/by/4.0/. 
higher education courses are less prevalent than in other jurisdictions such as Australia or the United States, but the number of students enrolling in online higher education courses in Ireland is growing, which is evident from the increase of online-only government sponsored Springboard degree courses, which grew from 10\% of courses in 2011 to 15\% in 2016 (HEA, 2016; HEA, 2018). However, online students have been shown to be more vulnerable to attrition, with online degree programmes having lower rates of completion in comparison with traditional ones (Woodley \& Simpson, 2014). Online students' lower completion rates may be attributed to issues with time management and lifeload, unrealistic expectations, a sense of isolation and a perception that they are less valued by the institutional culture (Brown, Hughes, Keppell, Hard, \& Smith, 2015; Mallman \& Lee, 2016; Nichols, 2011; O’ Shea, Stone, \& Delahunty, 2015). The reasons underlying online student non-completion are a complex set of factors which encompass student engagement and success, and it is therefore important that needs of online students are better understood to facilitate their success and engagement in higher education (Brunton, Brown, Costello, \& Farrell, 2018; Kahu \& Nelson, 2018).

There is very little literature about the experiences of online students in the Irish higher education (HE) context, with the majority of the relevant literature based in Australasia. While the experiences of campus based undergraduate students have been thoroughly explored, "the experiences of online students has been somewhat ignored in the literature" (O' Shea et al., 2015, p. 57). The current study focused on the experiences of online students in the Irish higher education context, aiming to improve our understanding of a cohort of students that is under researched in the Irish context.

\section{Contexts from the literature}

This section presents contexts from the literature about online student success, study habits and engagement. Student engagement can be defined as "a student's emotional, behavioural and cognitive connection to their study" which has a direct impact on student success and achievement (Kahu, Stephens, Zepke, \& Leach, 2014, p. 523). As online degree programmes have lower rates of retention and graduation than campus based undergraduate courses, it is important that a greater understanding of student engagement in the online context is developed (Woodley \& Simpson, 2014).

There are a number of interlinked factors reported in the literature which affect online student experiences and retention: time management skills; the ability to balance work, family, etc. with study; autonomy; community; sense of belonging; motivation; course design; and support structures at institutional, programme and teacher levels (Blackmon \& Major, 2012; Brown et al., 2015; Buck, 2016; Holder, 2007; Zembylas, Theodorou, \& Pavlakis, 2008).

The following sections present contexts from the literature about online student success, study habits and engagement through the lens of Kahu's (2013) holistic conceptual framework of student engagement. Kahu's (2013) framework has the student at the centre interacting: the social-cultural context, structural and psycho-social influences, engagement and the proximal and distal consequences, see Fig. 1 below.

In this study, there is a particular focus on the factors which are most relevant to online students, as "when shifting to online contexts, engagement takes on different manifestations, due to the lack of face to face contact and the ways in which teaching and learning are mediated through technology" (O' Shea et al., 2015, p. 43). 


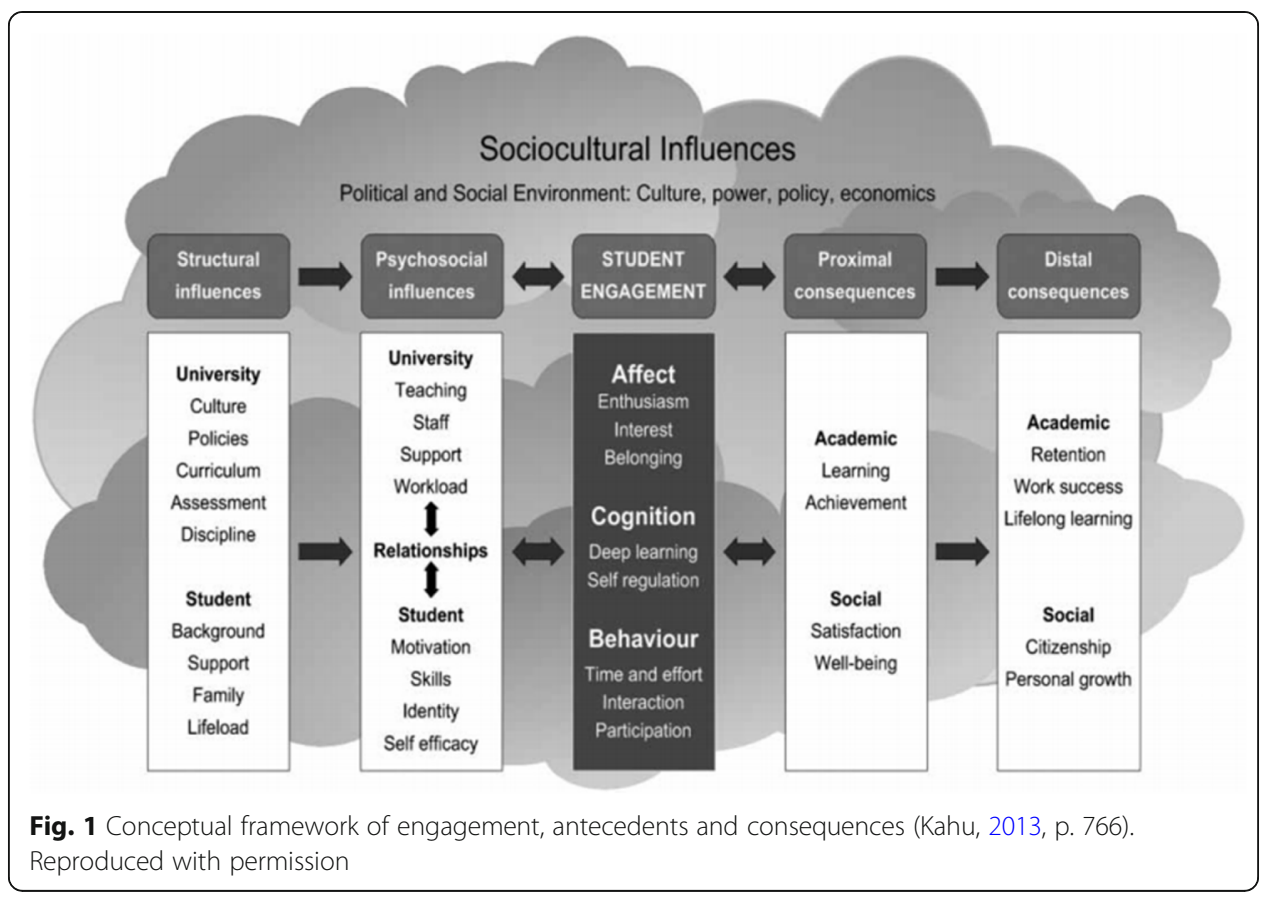

\section{Socio-cultural influences}

Recent high level international and Irish policy reports have emphasised the importance of lifelong learning and bringing more adult learners into higher education, through the provision of flexible study options such as online or part-time programmes (European Commission, 2014; Department of Education \& Skills, 2011). This strategy has led to a slow growth in the numbers of adult students participating in online higher education (HE) in Ireland. Online learning is more affordable as students can earn as they learn and travel costs are reduced. For these reasons, online learning is important in supporting access to HE for disadvantaged groups (Castaño-Muñoz, Colucci, \& Smidt, 2018).

Although access to Irish higher education has increased for adult learners, social inequalities continue to be reproduced, and some groups remain under-represented (Delaney \& Farren, 2016). Typically online students in Ireland are older and from lower socio-economic backgrounds, some are upskilling, and many are second chance learners, and there is an intersectionality between these identity categories (Brunton et al., 2018; Delaney \& Brown, 2018). Irish online students may have delayed participation in university education for reasons relating to social class (Delaney \& Farren, 2016).

\section{Structural influences}

For online students, structural influences such as course design significantly impact on their learning experiences. Online student engagement can be supported by a welldesigned course which promotes interaction and social presence and creates a clear, purposeful learning journey; efficient use of students' limited time; linking learning activities to goals; building on existing understanding whilst addressing gaps in understandings; providing immersive, real-world simulations or experiences (Buck, 2016; Frey, 2015). Inappropriately designed online courses and delivery can negatively impact on online student engagement (Stone \& O’Shea, 2019). 
In Ireland, HE institutional supports such as library, career advice, learning support, administration and counselling services are heavily focused on full time on campus students. This means that online students have reduced access or sometimes no access to vital university supports (Delaney \& Farren, 2016; HEA, 2012). This can lead to online students feeling less integrated and engaged with the institution and feeling that they are a lower priority than campus based students (HEA, 2012; O' Shea et al., 2015; Yang, Baldwin, \& Snelson, 2017). This can be seen as related to the barriers that exist for adult learners where the institution primarily serves, and is structured for younger students. Such barriers will impact on a sense of belonging as adult learners negotiate an institutional understanding of learners that runs contrary to their needs, experiences, and ways of being (Fairchild, 2003).

Online students tend to have many demands on their time; the very reasons which cause them to choose this study mode can in turn cause them to withdraw (Simpson, 2004). Many online students struggle to follow a regular study schedule due to the challenges of balancing work, family and study (Blackmon \& Major, 2012; Brown et al., 2015; Buck, 2016; Zembylas et al., 2008). Trying to fulfil multiple roles and juggle professional, family, social life, and study can cause online students to feel considerable stress (Brown et al., 2015; Stone \& O’Shea, 2019; Zembylas et al., 2008). Kahu (2013, p. 767) describes this as lifeload which "is the sum of all the pressures a student has in their life, including university", and is described as being a critical factor influencing student engagement. For online students, particularly those with caring responsibilities, support from family and friends is key to successful engagement enabling them to have time and space to study (Kahu et al., 2014; McGivney, 2004).

\section{Psychosocial influences}

Online student engagement is affected by a number of interrelated psychosocial influences such as teaching support, motivation, skills and self-efficacy.

Teaching support plays a critical role in online courses, with teacher engagement and connection having a positive effect on online student retention (Stone \& O'Shea, 2019). Effective online teachers support their students through timely, proactive, embedded support which establishes their personal presence and actively engages students through synchronous and asynchronous methods (Rose Sr., 2018; Stone \& O'Shea, 2019). Further, online student self-efficacy is a predictor of success. Kahu, Picton, \& Nelson, 2019) found that student self-efficacy influenced interest and enjoyment, and behavioural engagement with learning.

According to the literature, there are a number of key skills which contribute to successful study online such as organisation, time management, study skills and digital competencies (Andrews \& Tynan, 2012; Brown et al., 2015; Buck, 2016). Online learning is facilitated through digital technology and internet access. For online students having the necessary digital skills to comfortably and competently engage with the technological aspects of online learning can be a barrier to successful engagement with their online programmes (Brown et al., 2015; O' Shea et al., 2015). In particular, new online students struggle with the online learning environment and may need time and support to sufficiently orientate themselves (Stone \& O’Shea, 2019; Yoo \& Huang, 2013). 
Students with more developed time management skills are more likely to continue on an online course (Holder, 2007). This involves establishing a sustainable study routine which can adapt and account for problems (Brown et al., 2015; Kahu et al., 2014). In addition to time management, strong organisational skills and the ability to keep on task are key to being a successful online learner (Buck, 2016). Creating a positive study environment with a dedicated and quiet study space is an important organisational aspect for online students (Buck, 2016; Çakıroğlu, 2014). A further organisational aspect is the necessity to plan and structure their studies around their other responsibilities effectively, this can result in unusual study patterns which are highly individual such as studying late at night or early in the morning (Andrews \& Tynan, 2012; Buck, 2016).

\section{Student engagement}

In Kahu's (2013) framework, student engagement is influenced by the socio-cultural, structural, psychosocial factors discussed above. Further, online student engagement is particularly influenced by a sense of belonging. "Online learners, perhaps more so than face-to-face learners, need deliberately orchestrated, multiple opportunities to engage with others so that expression, development, tolerance and recognition of their diverse identities may in part compensate for any lack felt by not having a physical presence." (Delahunty, Verenikina, \& Jones, 2014).

Retention of online students can be facilitated by a strong sense of belonging to the institutional, programme and module community (Bowles \& Brindle, 2017; Farrell \& Seery 2019; Stone \& O'Shea, 2019). Feeling that they belong to a community of learners has a significant impact on the learning experiences of online students (Buck, 2016; O' Shea et al., 2015). The two factors that can support the development of a sense of community and belonging in students are establishing social presence and high levels of interaction in the course (Buck, 2016; Veletsianos \& Navarrete, 2012). Developing social presence in the course gives students a greater sense of connection to each other, the teacher and the course (Veletsianos \& Navarrete, 2012). Interaction and social presence can be promoted through course design which promotes active communication between students and instructors using asynchronous discussion forums and synchronous online classes (Buck, 2016). Community can also be fostered through informal student interaction such as social media, study groups, and email (O' Shea et al., 2015). Andrews and Tynan (2012) found that informal student networks were most beneficial for participants in terms of sense of community. Informal student networks can enable online students to form positive social relationships and close ties with fellow students (Zembylas et al., 2008). The emphasis in the literature on building community is in response to the feelings of isolation often experienced by online students (Bolliger \& Shepherd, 2010). Fostering a strong sense of community among students in online courses and establishing social presence can decrease students' feelings of isolation and disconnection (Phirangee \& Malec, 2017).

\section{Engagement-disengagement outcomes}

The outcomes or proximal/distal consequences of online student engagement are a positive learning experience, course completion and a sense of satisfaction (Kahu, 2013; Kahu et al., 2019; O' Shea et al., 2015). The outcomes of online student disengagement 
are non-completion, withdrawal, and unsatisfactory learning experience (Kahu, 2013; Kahu et al., 2019; O' Shea et al., 2015). The majority of students who withdraw do not return to study, emphasising the importance of targeted student success and engagement supports early in the study lifecycle (Brunton et al., 2018; Woodley \& Simpson, 2014).

In summary the literature highlights the importance of viewing online student engagement through the lens of socio-cultural, structural, and psychosocial influences. There is a gap in the research on the experiences of online students in Irish higher education, with the majority of the relevant literature based in Australasia, which identifies a gap for studies such as this can address.

\section{Our approach to online student engagement}

The DCU Connected approach to online student engagement comprises of a commitment to open access admission, a strategic approach to transition, flexible progression routes, a layered support system, a focus on student skills development, and a programmatic approach to online learning and assessment design, see Table 1 below.

\section{Methodology}

A qualitative case study grounded in the constructivist paradigm was designed with the aim of exploring online student engagement experiences. The present study was framed by the following research question:

Table 1 Our approach to online student engagement

\begin{tabular}{|c|c|}
\hline Access & $\begin{array}{l}\text { - Open access admission policy } \\
\text { - Flexible progression routes } \\
\text { - Student chooses credit load to align to lifeload }\end{array}$ \\
\hline $\begin{array}{l}\text { Strategic approach to } \\
\text { transition }\end{array}$ & $\begin{array}{l}\text { - Pre-entry: Online socialisation courses, welcome emails and phone calls } \\
\text { - On-entry: On campus and/or online orientation: including introduction to their } \\
\text { programme, socialisation with staff and students, campus tour, overview of univer- } \\
\text { sity support services, etc. } \\
\text { - New student mentor }\end{array}$ \\
\hline Support & $\begin{array}{l}\text { - Programme team support- Check-in emails and phone calls to identify at-risk stu- } \\
\text { dents, programme support hub on VLE } \\
\text { - Module tutor support- synchronous online seminars (evenings and weekends), } \\
\text { asynchronous discussion forums, email and phone support } \\
\text { - Institutional supports-library, student services, careers }\end{array}$ \\
\hline Skills development & $\begin{array}{l}\text { - Online training on the use of the VLE, online classrooms, online library resources } \\
\text { - Study skills instruction embedded in year one modules } \\
\text { - Additional study skills online seminars throughout the year }\end{array}$ \\
\hline Learning design & $\begin{array}{l}\text { - Modules designed for online delivery, following the ABC and Quality Matters } \\
\text { approaches (Quality Matters, 2019; Young \& Perović, 2018) } \\
\text { - Interactive learning resources, multimedia which are informed by usability and } \\
\text { accessibility standards } \\
\text { - Teacher presence established through welcome video, photo, approach to } \\
\text { facilitation } \\
\text { - Synchronous and asynchronous interaction }\end{array}$ \\
\hline Assessment & $\begin{array}{l}\text { - Programmatic approach to assessment and feedback, aligned to learning } \\
\text { outcomes and learning resources } \\
\text { - Consist approach to presentation of detailed assignment briefs } \\
\text { - Three-week turnaround on assignment feedback using consistent, detailed feed- } \\
\text { back forms } \\
\text { - Variety of assessment approaches } \\
\text { - Group work to facilitate sense of belonging }\end{array}$ \\
\hline
\end{tabular}




\section{What themes are central to online student engagement experiences?}

The setting for the study was an undergraduate sociology module on the BA (Hons) in $\mathrm{Hu}$ manities, an online programme delivered through DCU Connected at Dublin City University.

Ethical approval for the study was granted by the institutional research ethics committee. Purposive sampling was used to select participants for the case study. Twentyfour online, adult students gave written consent to take part in the study in the academic year 2016-2017. The cohort comprised of seven males and 17 females, participants' ages ranged from 21 to 63, with an average age of 39 years old, participants were geographically distributed around Ireland.

Data was collected in two ways: two semi-structured interviews per participant conducted mid-way and at the end of the academic year; and participant-generated learning portfolio entries relating to their learning experience in the sociology module. The interviews were conducted in real time online using a private Adobe Connect classroom. Participants completed five learning portfolio entries, approximately one per month over the academic year. In the learning portfolio entries, participants included visual and written reflections.

As insider researchers, who work in DCU, this has limitations for the study, as issues of power and bias can emerge (Sikes \& Potts, 2008). The issue of power was dealt through the use of institutional gatekeepers to access the study participants.

An iterative model of data collection and analysis was adopted. The analysis followed a data-led thematic analysis approach based on Braun and Clarke's (2006) six phases and comprised of several cycles of coding, theme generation, refining and reviewing themes. After a number of iterations of reviewing and refining, a thematic diagram was created and each theme was defined and named. Themes constructed through the analytical process are discussed in the findings below.

\section{Findings}

The findings presented below encapsulate the experiences of online students engaging with an undergraduate sociology module. Five themes were constructed during the analytical process, they were as follows: peer community, module supports, studying while balancing life commitments, confidence and my approach to learning. The final five themes created through the iterative analytic process, resulting in the final thematic map are presented in Fig. 2 below.

\section{Peer community}

In their narratives, the role of their peers as part of their learning experience in the module and as a source of support was valued. In the module discussion forums and online tutorials, discussion and debate with classmates enhanced student learning experiences and deepened their understanding of sociology.

"I feel I am fortunate enough to be in a group with classmates that encourage and engage in debates around various topics in sociology, whether it be in class, between breaks or through the online forum" (Participant 12, entry 1).

For participant 17, group discussions greatly facilitated his comprehension of the module concepts and content, "Listening to fellow students speak about their thoughts and ideas 


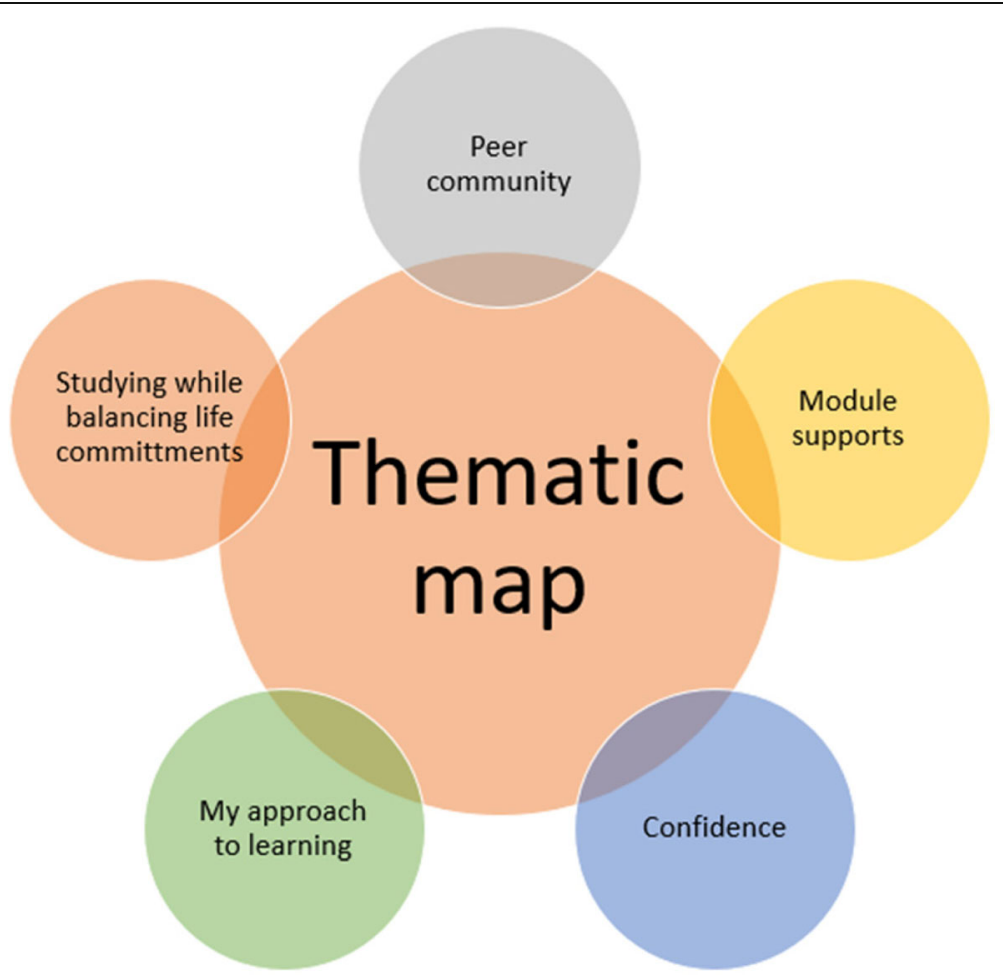

Fig. 2 Final Thematic Map: illustrating five themes constructed in the analytic process

about the various sociological institutions, such as education and religion made me realise that my knowledge of sociology is similar to others" (Participant 17, entry 1).

The students formed informal study groups organically, which met face to face, online and on Whatsapp, theyvalued the support, reassurance and sense of community offered by peers in these informal study groups.

I: it's great to hear what other people are doing as well because you know yourself studying online can be very isolating.

P5: Yeah, thank god for the Whatsapp groups.

I: Yeah well I have heard that they are very helpful all right.

P5: Yeah they really are when you get stuck you can just get on and say 'Lads I am fucking stuck' and someone will say 'What are you stuck on, what can you not get your head around?' And it is great for that. And also for reminding people when we have online.

I: Assignments due and stuff.

P5: It is just really good for that so you don't feel like you are on your own. (Participant 5, interview 1).

Both the formal and informal communities formed by the students and tutors in the module engendered a sense of belonging to the programme and was an integral part of their approach to learning in the module. 
"Yeah it's brilliant I have become friends with a few people in the course and some of them are over from different countries doing exams so we are thinking of going for drinks, we stay in touch." (Participant 10, interview 2).

Although many of the participants described feeling part of the class community, for two participants, studying online was an isolating experience.

"It is hard working alone and I do find that I can get a bit lost as there is not much direction from DCU as to what stage I should be at with my reading etc. This was brought up at the last tutorial but there has been no correspondence since. I think since my last post I have become a bit frustrated and have actually struggled even though I have organised myself a bit better. This sounds a bit contradictory but I think the lack of interaction with anyone is causing this." (Participant 1, entry 2).

\section{Module supports}

A high value on the support offered by their module tutors both in synchronous online sessions and asynchronous discussion forums was reported. Attending and participating in tutorials was described as fundamental to learning, socialization and progression in the module. Tutorials provided reassurance, interaction with peers and clarification of difficult concepts and theories.

"However, since then I have completed the postings for Assignment two and have attended another online tutorial. The tutorial covered the codes, conventions, theories and perspectives of Social Order. As I had been studying these subjects in the unit notes, it was very useful to have a structured discussion on them. When our tutor gives real life examples of the application of these, it makes everything easier to understand and remember. I thought that tutorial was particularly useful, as there was good interaction among the group. We were in the middle of our postings for assignment 2 at that time. (Tutor name) gave us useful pointers for the assignment, among which was to try to focus our examples on Irish society." (P8, eportfolio entry 4).

The importance and centrality of the support provided by the module tutors was very clearly articulated in the data. The reassuring and supporting role of the tutor was very significant to the learning experience of participants in terms of clarification of concepts and assignments, encouragement, guidance on reading and approaches to study.

"One of my main difficulties in gathering my work for the first assignment, was my block on getting over what the definition of power is in sociology. When we had our first face to face tutorial with (tutor name) it made more sense and I was actually surprised at how much power was evident in everyday life, in our relationships with people and in our interactions with pretty much everyone." (P5, entry 1).

Some participants described becoming more comfortable interacting on the online discussion forum, and perceived them to be a useful medium for interactive discussion 
and viewing other students' questions and concerns on the class discussion forum, which alleviated feelings of doubt.

"I learned that I like the interaction of the online forum for learning and I found it interesting to read what other people had researched. I found I was reading with a focus of either agreeing or disagreeing with the points that people had made. I had to choose which posts to engage with. The type of work in forums and engaging with others is helping me with my critical thinking skills." (P4 entry 4).

As a contrast, othersfelt nervous, exposed and disinclined to post on the discussion forum.

I: So I suppose the things that stand out to me are your pieces of evidence. Do you want to talk about them a little?

P19: Oh I forgot I posted that. So one of them was my reply to (tutor name) I think it is. It was about my confidence in using the forum, and participating in that way. Because I think you're hesitant, you don't know how people are going to take you up on the forums. And it's different from other bits of social media where you don't care how people take you up. You just have to be yourself. If somebody takes me up poorly, I'm going to come across poorly to my tutor. I might foster some kind of bias. (P19, Interview 1).

This means that discussion forums, which are a key mechanism of support within the module, do not meet the support needs of some students.

\section{Studying while balancing life commitments}

The data indicated that the most challenging aspect of being an online student was studying while balancing work, family and caring responsibilities. This is very clearly articulated in participant narratives. Balancing competing demands while finding sufficient time to study, and write assignments, put participants under severe pressure. As the students are already time poor, issues such as illness had a domino effect on participants' ability to keep on track with their studies. One or two unexpected problems in their personal lives could cause students to fall badly behind with their study and assignment work, thus impacting their learning experience.

"I'm beginning to worry that I won't have time for a more in depth look at everything in this section, before having to move on to Crime and Deviance in advance of Assignment 2. It all comes down to time management, which I remember was an issue at this time last year. With all the extra pressures of Christmas from a work and family point of view the study can get squeezed. I may have to do less(no?) housework to facilitate my learning this month. This idea has not been negotiated with my partner and may have to be revised! Perhaps a self-imposed ban on TV for the month is a more acceptable strategy. However, all work and no play!" (P20, entry 2).

The issue of time management is very strongly articulated in the data: the pressure of finding sufficient study time; and the stress and worry they felt about falling behind was a persistent difficulty faced by participants throughout the academic year. 
"My learning process is still haphazard and I struggle to block off sufficient time to study. I have dealt with this to some extent by spending longer hours in my office in work to catch up on my modules. The downside of this is I am available to work colleagues even though I am technically finished work and situations often arise that require my attention." (P3, entry 3).

The majority of participants proactively planned their study, many created study schedules and task lists which they included in their eportfolio entries. For some participants this systematic approach to planning study was effective, and the establishing of regular study routines enabled them to cope with coursework. Participant 17 demonstrated his approach in his study plan for January, see Fig. 3 below.

For other participants, despite good intentions about creating a regular study schedule, their challenges with time management persisted which continued to cause them considerable stress and anxiety.

"My learning process this year involved two strategies: firstly, snatching time whenever I could to get my college work done and secondly, descending into a blind panic at the last minute before having to submit work. These are not approaches that I would recommend or indeed intend to replicate as I go forward with this course." (P7, eportfolio entry 5).

\section{Confidence}

Expressions of self-doubt, fear, apprehension, uncertainty about their academic abilities and approaches to studying feature in participant narratives. This is evident in participant 15's extract below:

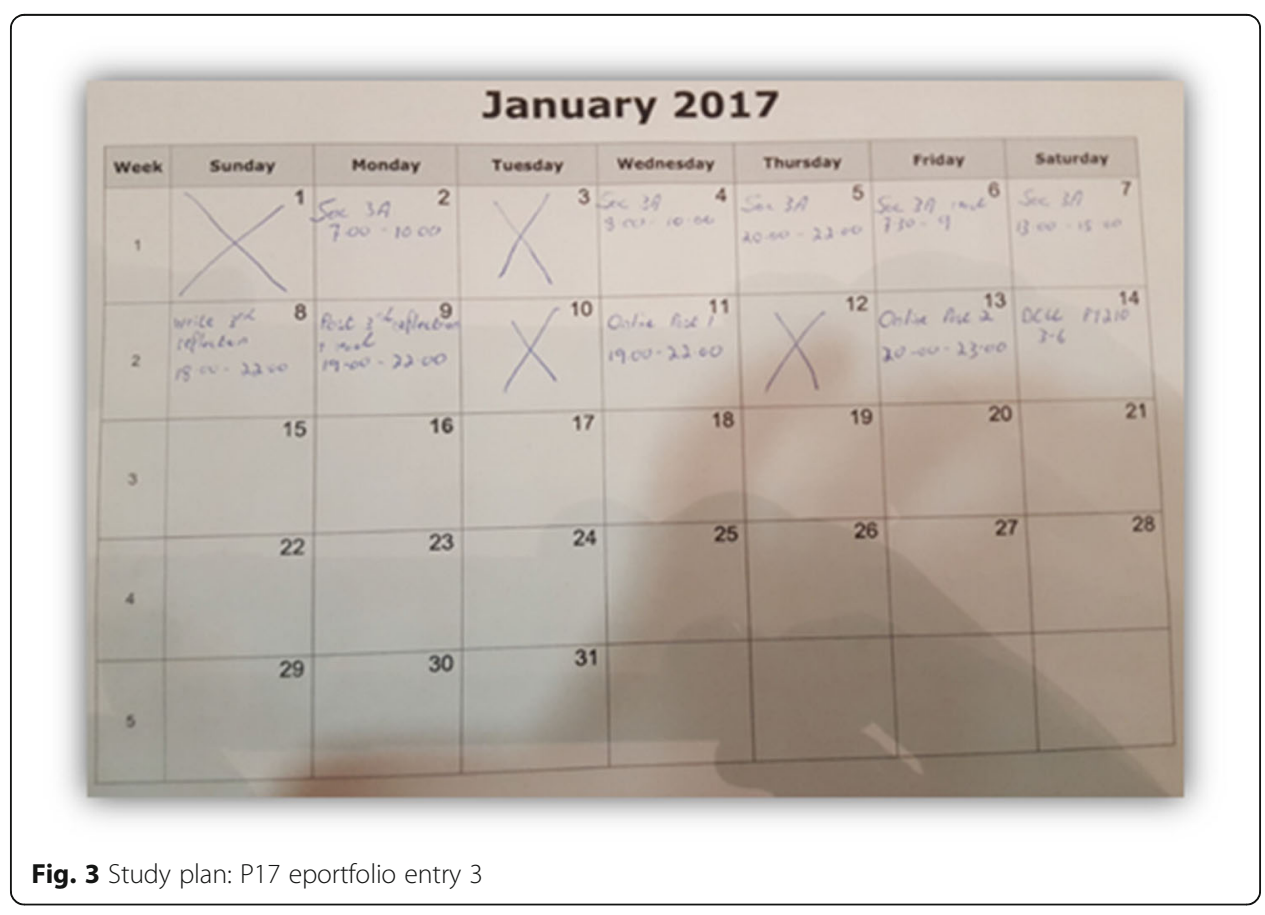


"I am very happy to see that over the past few months my reading skills have vastly improved. Before I started my journey of third level education, my reading skills were below average at the best of time, I had a lack of confidence in myself and I could not abstract information from a text on the best of days." (P15, eportfolio entry 3).

Some participants grew in confidence as the module progressed. Getting good assignment results and positive feedback validated their perceived abilities, and enabled them to overcome their feelings of uncertainty.

"Previously, I was unaware that self-doubt affected new writing challenges such as the SOC3A A1 article review. However, I was aware of a drive to learn and demonstrate knowledge of sociology to myself. I believe the grades validated my ability and I was no longer distracted or made anxious by self-doubt. Therefore, I have discovered growth in my confidence impacted my study habits and did not uncover contrary study habits." (P19, eportfolio entry 3).

By proactively addressing and overcoming their perceived academic weaknesses, some participants gained confidence in their academic abilities and felt well prepared for future study.

I: And do you feel more ready for next year?

P13: Totally. I mean, I think if you had asked at the start of the year how I would feel about third year I was just very overwhelmed, I was finding it so daunting and I feel like it is going to be fine, I really do. I feel like it is just going to be the same as this year with different assignment titles.

I: So, your confidence has grown?

P13: Oh, without a shadow of a doubt, yeah. I feel like I know how to study now, I know how to reference, I am organised, I have my diary for doing my timelines, I feel very ready.

I: That is great, so a big jump.

P13: Yeah. Big, big jump but I mean, I feel like it is progressing very well. (P13, interview 2).

\section{My approach to learning}

In their narratives, participants described their highly personal approaches to learning, this provides a detailed insight into their study techniques, when, where and how they learned. As the majority of study was self-directed, participants had to develop individual techniques to aid their understanding of the sociological content, theory and concepts. A variety of online student study approaches was detailed in the data. These techniques were varied, and innovative, describing traditional approaches such as reading, annotating and note taking and modern approaches to study using online resources such as YouTube videos, online lectures, podcasts, glossaries, online articles, and watching recordings of previous online tutorials. 
"My learning process begins with reading the module unit text to get an overview of the topic. I then re-read the text more carefully, underlining and annotating. If I find I need clarification on a concept or theory I use the internet to find either a useful article or video. I then move on to the required reading." (P18, entry 1).

Further, participant 18 provided the below image to evidence his learning approach, which he describes as "I have included this photograph of my annotated notes on Talcott, Gramsci and Foucault as evidence of my engagement with the module text. You can see that I underline or circle key terms. I also scribble down thoughts or connections I make", see Fig. 4 below.

Study techniques were detailed in the data, including approaches to reading and varied personal approaches to note-taking. Participants included many visual examples of their note-taking approaches which were highly individual. This individual approach is evident in participant 21's use of colour coding in her notes to aid revision, see Fig. 5.

"I have once again used the approach to study that I discovered most beneficial to me last year. I read through the topic that I am trying to learn. I highlight the information that I feel is beneficial and are the key points. I then add these key points to a note pad. I use different coloured pens for titles of topic's and the actual content so that when I look back over it, it can be easily found." (P21, entry 1).

In addition, participants reported studying in a wide range of places. They studied at home, in the library, on their phone while commuting to work, in cafes, in work. Participants were creative at carving out time and space to study, as evidenced in the quote below:

"I am a busy mother of five so... it would be difficult for me to get to classes so I find I work my study around the children. I keep books in my car and study while I wait at football practice and I love the fact that I can look over an online class later in the evening." (P14, entry 1).

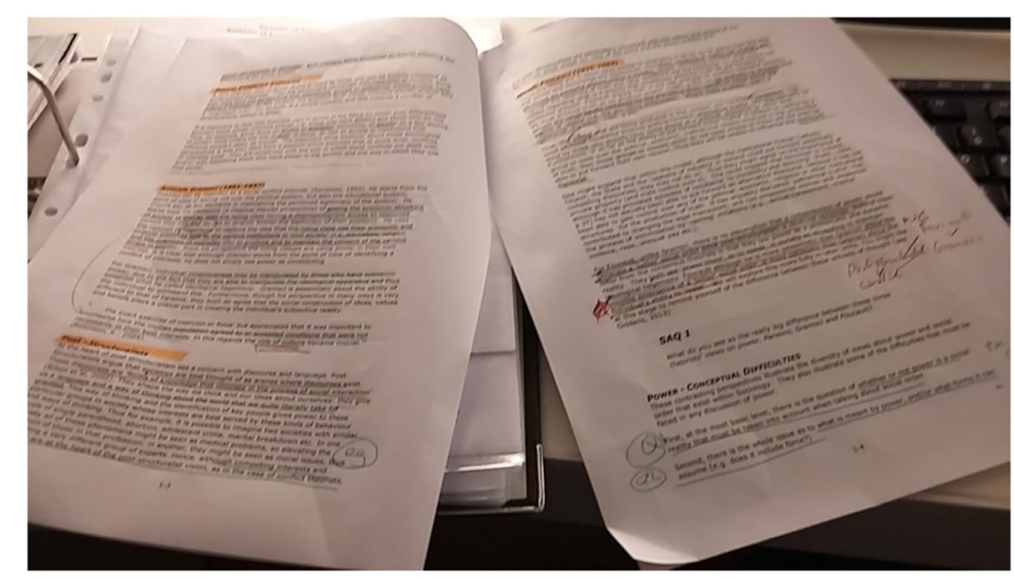

Fig. 4 My learning process (P18, entry 1) 


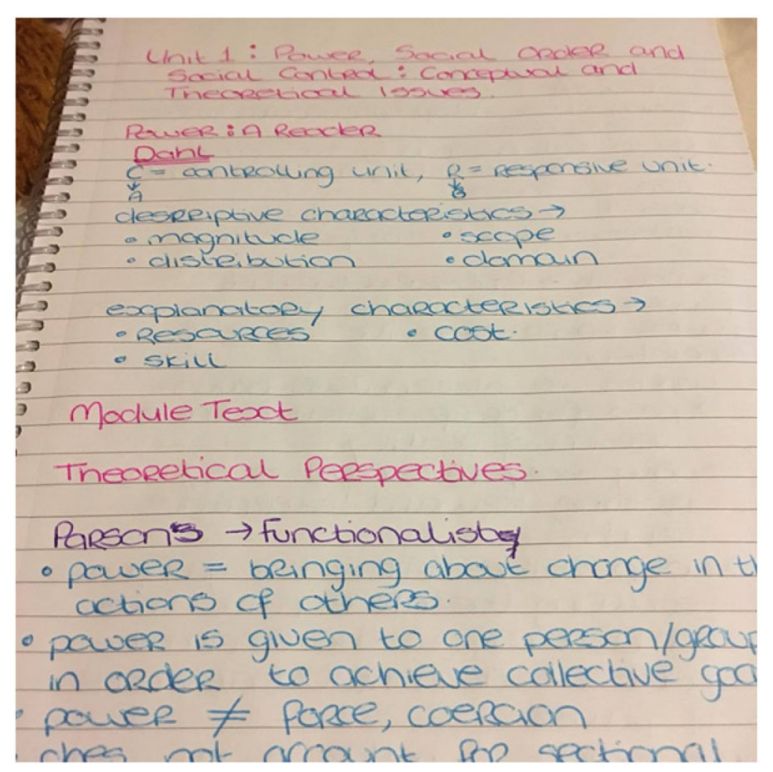

Fig. 5 A page of the notes I take showing the colour scheme (P21, entry 1)

Many included images of their study spaces, for example participant 18 evidenced his study space in the image in Fig. 6 below, which he described as "the view from the window of my attic office" (P18, entry 5).

To summarise the findings section above, the key factors to the engagement and success of this particular cohort of online students were: community, time management and organisational skills, engaging and supportive online teachers, multiple means of interaction and opportunities to develop skills and build confidence.

\section{Discussion}

The purpose of this study was to explore themes relating to online student engagement experiences. This section discusses the findings of the study in relation to Kahu's

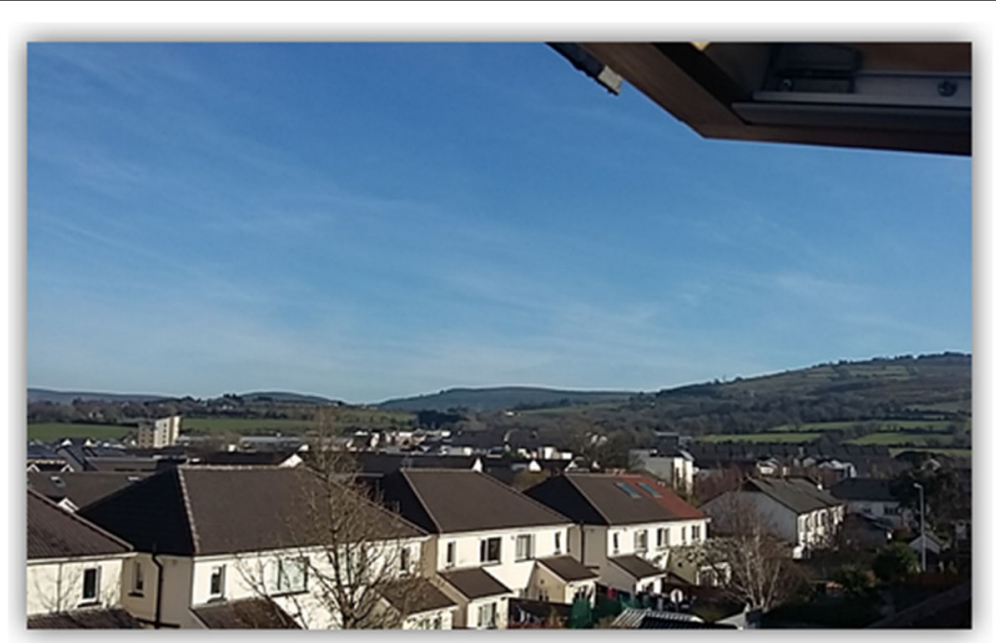

Fig. 6 The view from my attic office. (P18, eportfolio entry 5) 
(2013) holistic conceptual framework of student engagement, the research question and the existing literature.

The findings from this study indicate that being a successful online student was impacted by the structural influence of lifeload. It was found that the most challenging aspect of being an online learner was balancing one's studies with other highly valued and time-consuming commitments, such as work, family and caring responsibilities. This is consistent with previous research which found that trying to fulfil multiple roles and juggle professional, family, social and study contexts can cause online distance students to experience considerable stress (Brown et al., 2015; Kahu et al., 2014; Zembylas et al., 2008).

A further structural influence on online student engagement in this study, was the design-led approach to use of discussion forums in this sociology module. Asynchronous discussion forums were used as a place to ask questions, seek support and interact with the module tutor and classmates. Discussion forums were used in conjunction with synchronous online seminars for the purpose of interacting with others in the module. In this study, there were mixed reactions from participants about the usefulness of discussion forums. For some participants, discussion forums were useful for interactive discussion and viewing other students' questions and concerns. Other participants felt nervous, exposed and were disinclined to post on the discussion forums. This finding differs with the literature which indicates that active communication between students and instructors using asynchronous discussion forums promotes interaction and social presence (Buck, 2016; Gauvreau, Hurst, Cleveland-Innes, \& Hawranik, 2016). This means that discussion forums which were a key mechanism of support in the module did not meet the support needs of some students.

A key psychosocial influence on online student engagement was found to come from interaction with the peer community, which engendered feelings of belonging and support. Participants placed a high value on the peer communities they formed over the course of the academic year. Three types of formal and informal peer communities were formed: the official institutional community; the studentgenerated and student-led class community; and smaller cohorts of studentgenerated study groups. These peer communities were perceived by participants to be an essential source of support, reassurance, encouragement and human connection. This finding is consistent with previous research on peer interaction in online courses carried out by Andrews and Tynan (2012), O' Shea et al. (2015), Zembylas et al. (2008). Further, a proximal consequence of the strong peer community formed was an enhanced learning experience through discussion and debate in the module discussion forums. Despite the presence of a strong class community within the cohort, the findings from this study suggest that for a small number of participants, being an online student was an isolating experience which may have caused or contributed to disengagement with the module. This is in line with previous research which evidenced that feelings of isolation were often experienced by online distance students (Bolliger \& Shepherd, 2010; Phirangee \& Malec, 2017).

The module tutor played a very significant role in participants reported online learning engagement experiences. The data revealed that participants placed a high value on the support, reassurance and guidance provided by the module tutor. These findings 
reinforce the central role of the online teacher for online student success and engagement evidenced in the literature (Buck, 2016; Gauvreau et al., 2016; O' Shea et al., 2015).

The data revealed that developing time management and organisational skills were key skills for online student success and engagement, which enabled students to balance their lifeload and study. Successful online students developed creative strategies to carve out study time in their already busy lives. This is evident in the unusual and personal study patterns and locations reported. However, this study suggests that for some participants, challenges with time management persisted, causing stress, anxiety and disengagement. These findings ehco previous research which details the persistent challenge for online students to follow a regular study schedule (Blackmon \& Major, 2012; Brown et al., 2015; Buck, 2016; Darmody \& Fleming, 2009; Kahu et al., 2014).

Confidence or self-efficacy was also found to have a psychosocial influence on participants' learning experiences. At the start of the module, some participants expressed feelings of self-doubt, fear, apprehension, uncertainty and that they lacked confidence about their own academic abilities and approaches to studying. For some participants, achievement in assignments had a positive impact on their confidence. Those who engaged in self-regulatory behaviour and proactively addressed their perceived academic weaknesses gained confidence in their academic abilities, which is a point supported by the literature on confidence and online students (Baxter, 2012, O' Shea et al., 2015).

Strongly emphasised within participant data was the importance of the time and effort they invested in their learning, which is evident in their highly personal approaches to studying. These provide a detailed insight into the study approaches of online students; when, where and how they learned. These study techniques were varied, and innovative, describing traditional approaches such as reading, annotating and note taking and modern approaches to study using online resources such as YouTube videos, online lectures, podcasts, glossaries, online articles and watching recordings of previous online tutorials. Although the approaches to learning and the study techniques of online learners in this study were highly individual, they still conformed to traditional approaches to study such as note taking, reading, assignment preparation and writing. This is broadly in line with previous research carried out by Orton-Johnson (2008) and Çakıroğlu (2014) which found that the study habits of online students follow traditional study activities such as reading, note taking and writing assignments and are similar to campus-based students.

In summary, what has emerged from this study as being most important to the engagement and success of this particular cohort of online students, is as follows:

- Formal and informal community;

- Time management and organisational skills;

- Engaging and supportive online teachers;

- Multiple means of interaction, not just forums;

- Opportunities for skill development, confidence building and self-regulation.

\section{Conclusions}

The purpose of this study was to explore the themes that are central to online student engagement experiences in Irish higher education. The findings of this study indicate that successful online student engagement was influenced by a number of psychosocial 
factors such as peer community, an engaging online teacher, and confidence or selfefficacy and by structural factors such as lifeload and course design. Time management and organisational skills were key skills for online student success and engagement, which enabled students to balance their lifeload and study, however the study indicates persistent challenges for online students to follow a regular study schedule. One limitation of this study, is that it is a relatively small in-depth qualitative case study. However, its findings provide insights into important themes relating to online student engagement, which may inform research practice. For those supporting, teaching and designing online courses, being cognisant of the psychosocial and structural factors that affect online student engagement is valuable. Future research could further examine individual factors which influence online student engagement such as time.

Acknowledgements

Not applicable.

\section{Authors' contributions}

OF collected and analysed the data and drafted the first draft article. JB contributed to the literature review, methodology and findings sections and substantially edited and revised the first draft article. The author(s) read and approved the final manuscript.

\section{Funding}

No funding was received.

\section{Availability of data and materials}

The datasets generated and/or analysed during the current study are not publicly available due to ethical restrictions but are available from the corresponding author on reasonable request.

\section{Competing interests}

The authors declare that they have no competing interests.

Received: 27 August 2019 Accepted: 31 March 2020

Published online: 29 April 2020

\section{References}

Andrews, T., \& Tynan, B. (2012). Distance learners: Connected, mobile and resourceful individuals. Australasian Journal of Educational Technology, 28(4), 565-579.

Baxter, J. A. (2012). Who am I and what keeps me going? Profiling the distance learning student in higher education. The International Review of Research in Open and Distributed Learning, 13(4), 107-129. https://doi.org/10.19173/irrodl.v13i4. 1283.

Blackmon, S. J., \& Major, C. (2012). Student experiences in online courses: A qualitative research synthesis. Quarterly Review of Distance Education, 13(2), 77-85.

Bolliger, D. U., \& Shepherd, C. E. (2010). Student perceptions of Eportfolio integration in online courses. Distance Education, 31(3), 295-314. https://doi.org/10.1080/01587919.2010.513955.

Bowles, T. V., \& Brindle, K. A. (2017). Identifying facilitating factors and barriers to improving student retention rates in tertiary teaching courses: A systematic review. Higher Education Research \& Development, 36(5), 903-919. https://doi.org/10.1080/ 07294360.2016 .1264927$.

Braun, V., \& Clarke, V. (2006). Using thematic analysis in psychology. Qualitative Research in Psychology, 3(2), 77-101. https:// doi.org/10.1191/1478088706qp063oa.

Brown, M., Hughes, H., Keppell, M., Hard, N., \& Smith, L. (2015). Stories from students in their first semester of distance Learning. The International Review of Research in Open and Distance Learning, 16(4), 1-17.

Brunton, J., Brown, M., Costello, E., \& Farrell, O. (2018). Head start online: flexibility, transitions and student success. Educational Media International, 55(4). https://doi.org/10.1080/09523987.2018.1548783.

Buck, S. (2016). In their own voices: Study habits of distance education students. Journal of Library \& Information Services in Distance Learning, 10(3-4), 137-173. https://doi.org/10.1080/1533290X.2016.1206781.

Çakıroğlu, Ü. (2014). Analysing the effect of learning styles and study habits of distance learners on learning performances: A case of an introductory programming course. The international review of research in Open and distributed Learning, 15(4). https://doi.org/10.19173/irrodl.v15i4.1840.

Castaño-Muñoz, J., Colucci, E., \& Smidt, H. (2018). Free digital Learning for inclusion of migrants and refugees in Europe: A qualitative analysis of three types of Learning purposes. The International Review of Research in Open and Distance Learning, 19(2), 1-21.

Darmody, M., \& Fleming, B. (2009). 'The balancing act' - Irish part time undergraduate students in higher education. Irish Educational Studies, 28(1), 67-83. https://doi.org/10.1080/03323310802597333.

Delahunty, J., Verenikina, I., \& Jones, P. (2014). Socio-emotional connections: Identity, belonging and learning in online interactions. A literature review. Technology, Pedagogy and Education, 23(2), 243-265. https://doi.org/10.1080/1475939X. 2013.813405 
Delaney, L., \& Brown, M. (2018). To walk invisible: Distance students in a dual mode university. Distance Education, 39(2), 209223. https://doi.org/10.1080/01587919.2018.1457948.

Delaney, L., \& Farren, M. (2016). No 'self' left behind? Part-time distance learning university graduates: Social class, graduate identity and employability. Open Learning: The Journal of Open, Distance and e-Learning, 31(3), 194-208. https://doi.org/10 1080/02680513.2016.1208553.

Delaney, L., Fox, S. (2013). The role of distance education in broadening access to Irish higher education. In: How equal? Access to higher education in Ireland, 7 Nov 2013, Dublin, Ireland. Retrieved 13th January, 2018, from http://doras.dcu. ie/19966/

Department of Education and Skills. (2011). National Strategy for Higher Education to 2030 Report of the Strategy Group. Dublin: Department of Education and Skills.

European Commission (2014). Report to the European commission on new models of learning and teaching in higher education. Luxembourg: Publications Office of the European Union Retrieved from http://ec.europa.eu/education/library/reports/ modernisation-universities_en.pdf.

Fairchild, E. E. (2003). Multiple roles of adult learners. New Directions for Student Services, 102, 11-16. https://doi.org/10.1002/ss. 84

Farrell, O., \& Seery, A., (2019). "I am not simply learning and regurgitating information, I am also learning about myself": learning portfolio practice and online distance students. Distance Education, 40(1). https://doi.org/10.1080/01587919.2018. 1553565.

Frey, J. (2015). The importance of learning experience design for higher education. Retrieved from http://www.gettingsmart. com/2015/04/the-importance-of-learning-experience-design-for-higher-education/

Gauvreau, S. A., Hurst, D., Cleveland-Innes, M., \& Hawranik, P. (2016). Online Professional Skills Workshops: Perspectives from Distance Education Graduate Students. The International Review of Research in Open and Distributed Learning, 17(5). https://doi.org/10.19173/irrodl.v17i5.2024.

HEA (2012). Part-time and flexible higher education in Ireland. Dublin: HEA Retrieved May 11, 2019, from https://www.dkit.ie/ system/files/HEA\%20Report\%20on\%20Lifelong\%20Learning\%202013.pdf.

Higher Education Authority. (2016). Developing Talent,Changing Lives. An Evaluation of Springboard+, 2011-16. Retrieved June 13, 2019, from https://hea.ie/resource-year/2019/publications/https://hea.ie/resource-year/2019/publications/

Higher Education Authority. (2018). Key Facts \& Figures: Higher Education 2017/18. Retrieved June 13, 2019, from https://hea. ie/resource-year/2019/publications/https:/hea.ie/resource-year/2019/publications/

Holder, B. (2007). An investigation of hope, academics, environment, and motivation as predictors of persistence in higher education online programs. The Internet and Higher Education, 10(4), 245-260. https://doi.org/10.1016/j.iheduc.2007.08. 002.

Kahu, E. R. (2013). Framing student engagement in higher education. Studies in Higher Education, 38(5), 758-773. https://doi. org/10.1080/03075079.2011.598505.

Kahu, E. R., \& Nelson, K. (2018). Student engagement in the educational interface: Understanding the mechanisms of student success. Higher Education Research \& Development, 37(1), 58-71. https://doi.org/10.1080/07294360.2017.1344197.

Kahu, E. R., Picton, C., \& Nelson, K. (2019). Pathways to engagement: A longitudinal study of the first-year student experience in the educational interface. Higher Education. https://doi.org/10.1007/s10734-019-00429-w.

Kahu, E. R., Stephens, C., Zepke, N., \& Leach, L. (2014). Space and time to engage: Mature-aged distance students learn to fit study into their lives. International Journal of Lifelong Education, 33(4), 523-540. https://doi.org/10.1080/02601370.2014. 884177.

Mallman, M., \& Lee, H. (2016). Stigmatised learners: Mature-age students negotiating university culture. British Journal of Sociology of Education, 37(5), 684-701. https://doi.org/10.1080/01425692.2014.973017.

McGivney, V. (2004). Understanding persistence in adult learning. Open Learning, 19(1), 33-46.

Nichols, M. (2011). Intervention for retention through distance education: A comparison study, Project output ed (). New Zealand: Aotearoa: National Centre for Tertiary Teaching Excellence.

O' Shea, S., Stone, C., \& Delahunty, J. (2015). "I 'feel' like I am at university even though I am online." exploring how students narrate their engagement with higher education institutions in an online learning environment. Distance Education, 36(1), 41. https://doi.org/10.1080/01587919.2015.1019970.

Orton-Johnson, K. (2008). The online student: Lurking, chatting, flaming and joking. Sociological Research Online., 12(6). https:// doi.org/10.5153/sro. 1615

Phirangee, K., \& Malec, A. (2017). Othering in online learning: An examination of social presence, identity, and sense of community. Distance Education, 38(2), 160-172. https://doi.org/10.1080/01587919.2017.1322457.

Quality matters (2019) Higher Ed. Standards. Accessed from https://www.qualitymatters.org/qa-resources/rubric-standards/ higher-ed-rubric.

Roll, I., Russell, D. M., \& Gašević, D. (2018). Learning at scale. International Journal of Artificial Intelligence in Education (2018), 28(4), 471-477. https://doi.org/10.1007/s40593-018-0170-7.

Rose Sr., M. (2018). What are some key attributes of effective online teachers? Journal of Open, Flexible and Distance Learning, 22(2), 32-48.

Sikes, P., \& Potts, A. (2008). Researching education from the inside. London: Routledge.

Simpson, O. (2004). Supporting students for success in online and distance education. New York: Routledge. https://doi.org/10. 4324/9780203416563.

Stone, C., \& O'Shea, S. (2019). Older, online and first: Recommendations for retention and success. Australasian Journal of Educational Technology, 35(1), 57-69. https://doi.org/10.14742/ajet.3913.

Veletsianos, G., \& Navarrete, C. C. (2012). Online social networks as formal Learning environments: Learner experiences and activities. The International Review of Research in Open and Distributed Learning, 13(1), 144-166.

Woodley, A., \& Simpson, O. (2014). Student dropout: The elephant in the room, Online distance education: Towards a research agenda, 459-484 (). Canada: Athabasca University.

Yang, D., Baldwin, S., \& Snelson, C. (2017). Persistence factors revealed: Students' reflections on completing a fully online program. Distance Education, 38(1), 23. https://doi.org/10.1080/01587919.2017.1299561. 
Yoo, S. J., \& Huang, W. D. (2013). Engaging online adult learners in higher education: Motivational factors impacted by gender. Age, and Prior Experiences, The Journal of Continuing Higher Education, 61(3), 151-164. https://doi.org/10.1080/ 07377363.2013 .836823

Young, C., \& Perović, N. (2018). ABC Learning Design.

Zembylas, M., Theodorou, M., \& Pavlakis, A. (2008). The role of emotions in the experiences of online Learning: Challenges and opportunities. Educational Media International, 45(2), 107-117. https://doi.org/10.1080/09523980802107237.

\section{Publisher's Note}

Springer Nature remains neutral with regard to jurisdictional claims in published maps and institutional affiliations.

Submit your manuscript to a SpringerOpen ${ }^{\odot}$ journal and benefit from:

- Convenient online submission

- Rigorous peer review

- Open access: articles freely available online

High visibility within the field

- Retaining the copyright to your article

Submit your next manuscript at $\boldsymbol{\nabla}$ springeropen.com 